\title{
REPORTAGEM, MEMÓRIA E HISTÓRIA NO JORNALISMO BRASILEIRO*
}

Alexandre Bergamo

Nos últimos anos tem se multiplicado o número de artigos e teses preocupados em discutir a identidade do jornalismo. ${ }^{1}$ Observa-se, nessa discussão, uma especificidade ligada ao fato de que o jornalismo é uma atividade que produz diariamente registros tomados como fonte de informação num sentido amplo e, principalmente, de marcação no sentido histórico. Conforme afirma Letícia Cantarela Matheus:

As marcas do tempo são especialmente sensíveis nos jornais, localizando o leitor num "lugar" na duração. O consumo diário das narrativas jornalísticas fornece um forte parâmetro espaço-temporal. [...] A marcação do tempo foi se tornando função essencial dos jornais, a ponto de lhes ser dada credibilidade para datá-lo (Matheus 2010b:2-3).

Identidade e memória jornalística são, no interior dessa discussão, concepções tomadas como possuidoras de uma relação direta. A afirmação abaixo é um bom exemplo tanto da importância atribuída à profissão, em função dessa produção diária de registros e marcadores temporais, quanto da identidade buscada por esses profissionais, cuja marca maior é justamente essa produção de registros:

[O] descaso em relação à memória da imprensa traduz em certo sentido a atitude pátria referente à própria memória nacional, principalmente no âmbito da cultura não erudita, condenando ao esquecimento as instituições, os fatos e os personagens que também fizeram história (Marques de Melo 2005b:8).

Mas quais são, exatamente, as características e os critérios utilizados para a elaboração dessa identidade? Talvez possamos, para responder a esta questão, colocá-la em outros termos: quando os jornalistas falam de seu ofício, do que e de quem estão falando? Quais as funções, as atividades 
e os jornalistas considerados como referência para que eles possam pensar a si mesmos? E de que maneira a construção dessa referência implica não apenas uma forma de olhar para o presente da profissão, mas também para seu passado? Quais os critérios utilizados por eles para pensar uma "memória" para a profissão e por que o descaso em relação a ela é tomado como um descaso em relação à própria "memória nacional"? Sabemos que, por um lado, o conjunto das matérias jornalísticas representa um importante fragmento dessa chamada "memória nacional". Mas, por outro, nem todas as matérias são tomadas por esses mesmos profissionais como representativas de "sua memória".

Talvez um pequeno exemplo possa ilustrar melhor isso. Sabemos que o jornalismo brasileiro contou - e ainda conta - com grandes escritores. Mas, quando se pensa em jornalismo e jornalistas, são esses escritores e suas crônicas que vêm à mente desses profissionais?

Quando penso em jornalismo, aqui, penso em notícia, fatos. Não me passa pela cabeça a crônica. Não penso em nada que não tenha referência direta, indestrutível, no reconhecido, naquilo que ao menos mais de uma pessoa viu.

Estamos no século XXI. Só posso, hoje, conceber o jornalismo assim — uma relação multilateral, no mínimo triangular. Penso em retratos duros [...]

Houve um tempo em que o jornalismo representava mais, em que formava o único canal para toda manifestação escrita e pública. Esse tempo acabou. [...]

Penso num jornalismo útil, imediato, informativo, formador e lúcido (Ajzenberg 2002:53-54).

O Brasil conta atualmente com algo em torno de 100 mil jornalistas, ${ }^{2}$ os quais desenvolvem atividades as mais variadas, seja em jornal, rádio, televisão ou revista, seja no ensino, seja em assessorias de imprensa diversas, ou em outras funções possíveis. Mas, para a compreensão da forma como eles constroem sua identidade, sua memória e a sua história, não basta apenas contar números ou detalhar funções, é necessário detectar o que eles recomendam e o que eles estigmatizam, seja ao olharem para si mesmos no presente, seja ao olharem para o passado. Apesar do grande número de profissionais e da variedade de funções, há um léxico, práticas e personagens em comum utilizados para "informar" os critérios, os valores e as formas de atuação na área. Mas, principalmente, há uma atividade, a reportagem, entendida por todos como a essência mesma da profissão. Ainda que nem todos os jornalistas se definam como repórteres, a atividade é considerada "formadora" no exercício da profissão. É do final dos anos 1930 a publicação do Decreto-Lei que regula a profissão de jornalista. Trata-se do Decreto-Lei 
$\mathrm{n}^{\circ}$ 910, de 30 de novembro de 1938. De acordo com o Capítulo I Art. $1^{\circ} \S 1^{\mathrm{o}}$ : "Entende-se como jornalista o trabalhador intelectual cuja função se estende desde a busca de informação até a redação de notícias e artigos e a organização e direção desse trabalho".

Ou seja, na primeira definição "oficial" para a profissão estão a atividade hoje conhecida como reportagem ("a busca de informação até a redação de notícias e artigos") e o comando ("organização e direção") do jornal. Outro detalhe da maior importância é que se trata de um "trabalhador intelectual". Não é minha intenção aqui proceder a uma gênese do jornalismo no Brasil. Pretendo demonstrar, ao invés disto, como mudanças recentes no exercício da profissão estão sendo capazes de redefinir, por um lado, a reportagem e, por outro, a forma como esses profissionais olham para si mesmos no presente e, consequentemente, como olham para seu passado, para sua própria "história".

Sou relutante quanto à escolha de algum grupo de profissionais ou de algum jornal específico seja para a elaboração de um "retrato de corpo inteiro", seja para a análise de seus mecanismos de expressão, quando essa escolha implica deixar de lado as posições de menor prestígio. Embora esse procedimento seja revelador das relações de poder nas posições dominantes de certa área, diferentemente das elites artísticas e culturais, "existir socialmente" nas profissões ligadas à indústria cultural é algo que depende de formas de legitimação ora semelhantes às das elites artísticas e culturais - semelhança esta que traduz a aproximação entre as posições dominantes na indústria cultural e as formas artísticas e culturais consagradas $^{3}$ - ora divergentes, divergência esta capaz de marcar uma distinção e autonomia diante dessas mesmas manifestações consagradas. No caso do jornalismo, essa distinção ganha tradução por meio de um "estilo" próprio para a escrita e a apresentação de notícias, materializado, a partir dos anos 50, pelos "manuais de redação e estilo": "Houve uma fase em que a ruptura com o modelo literário se impunha e significou uma libertação para o texto jornalístico" (Silva 2002:51).

É necessário que se compreenda melhor, com isso, a ambiguidade de uma profissão marcada ora por sua dependência das formas artísticas e culturais consagradas, ora pela sua singularidade, especificidade e autonomia em face das mesmas. Essa singularidade e especificidade podem ser mais bem observadas não na concorrência entre as posições de prestígio da indústria cultural e as manifestações artísticas e culturais consagradas, disputa por posições muitas vezes próximas, algumas vezes em comum, mas sim na definição de uma fronteira capaz de separar essas posições de maior prestígio daquelas de menor ou nenhum prestígio. 
Eis a questão central, a meu ver: "existir socialmente" no interior das profissões ligadas à indústria cultural. No caso específico do jornalismo, creio que seja decisivo, nesse sentido, compreender melhor a tensão que separa as posições de maior prestígio, inclusive aquelas consideradas "exemplares", ou seja, as trajetórias dos "grandes nomes" da profissão, os quais devem ser conhecidos e lembrados pelos "novos", e as de menor prestígio. Estas, de menor valor, têm algo de "indizível": sobre elas nada é dito. Contudo, o "indizível" das posições ou das funções menos valorizadas traduz aquilo que é indizível na construção da identidade dos jornalistas, portanto, aquilo que deve ser "apagado" dessa mesma identidade.

O presente artigo representa um esforço para a compreensão do que seja esse "existir socialmente" no interior do jornalismo nos dias de hoje, o que deve ser declarado e o que deve ser ocultado na produção de uma legitimidade social para a profissão, na produção de um "sentido" para o seu exercício diário ou para a elaboração de uma identidade, de uma memória e de uma história próprias. Também representa um esforço no sentido de articular conflitos internos e aqueles, de caráter mais externo, ligados à reorganização ocorrida, nos últimos anos, no mercado de trabalho da profissão. Para tanto me apoio: na minha própria e em outras etnografias do jornalismo, em particular do espaço da redação; na especificidade da "notícia" e, principalmente, da "reportagem" enquanto um "documento" histórico, discussão necessária para a compreensão da vinculação que se estabelece entre a "memória jornalística" e a "memória nacional"; e nos efeitos que a imposição de um "estilo jornalístico", a exigência do diploma e a reorganização do mercado de trabalho tiveram e têm - sobre a organização e a escrita, cada vez mais sistematizada, das trajetórias consideradas exemplares para a área.

\section{A rotina da produção de notícias e os usos da linguagem}

Embora a etnografia que eu tomo como ponto de partida seja a minha própria, sobre o telejornalismo, a maior parte das questões aqui discutidas é válida para o trabalho do jornalista em outros veículos. ${ }^{4}$ Ainda que haja especificidades nesses veículos, que podem ser notadas quando comparamos as diversas fontes disponíveis, elas não invalidam o argumento aqui proposto, realizado com a preocupação de referir-se às tensões que marcam o "cotidiano" da elaboração de notícias de uma forma geral.

A estrutura para a produção diária dos telejornais também pode representar uma pedra no caminho. [...] Nunca parei para contabilizar, mas é comum, no 
caso do Jornal Nacional, mais de 50 repórteres saírem às ruas todos os dias atrás das notícias mais importantes. E eles sabem que, por melhor que possam ser seus desempenhos, por absoluta falta de espaço, apenas vinte por cento terão alguma chance de transmiti-las aos telespectadores (Barcelos 1994:19).

O depoimento acima reproduz, ao mesmo tempo, os obstáculos cotidianos da profissão e a tensão vivida pelos profissionais do telejornalismo diante desses obstáculos. A concorrência entre os jornalistas para a execução de matérias vem aliada a um trabalho que, na maior parte das vezes, pode não ter nenhuma recompensa, nenhum reconhecimento, uma vez que boa parte dele poderá vir a ser inutilizado, ignorado. Já outras matérias podem ser consideradas sem data, geralmente aquelas que tratam de "comportamento", e assim serem encaminhadas para a "geladeira", um arquivo de matérias "frias" para serem usadas quando o telejornal tiver algum "buraco" na pauta. ${ }^{5}$ Evidentemente, os "buracos" acontecem nas afiliadas das grandes emissoras, na grade de programação do telejornal local. Os jornais considerados "cabeças de rede" recebem notícias de todas as afiliadas do país, além das notícias internacionais, não correndo o risco de terem um buraco na pauta. Com isso, há uma tensão diária que marca a rotina desses profissionais, o que é válido também para os outros veículos, que reside na possibilidade de ver seu trabalho incluído ou excluído da pauta do telejornal, de realizar, ao longo do dia, matérias consideradas "quentes" ou "frias", segundo o jargão da área. ${ }^{6}$

Além disso, o depoimento expressa a opinião daqueles que estão — ou estavam, naquele momento - excluídos das posições de decisão sobre quais notícias serão ou não incluídas na edição do telejornal, ou seja, não é o repórter quem tem esse poder de decisão. Este é um detalhe da maior significação, uma vez que o jornalismo se define, basicamente, pela reportagem.

Independentemente do trabalho competente que desenvolvem, não cabe a eles a decisão sobre qual é a matéria mais relevante a ser apresentada, assim como também não cabe, no início do trabalho, muitas vezes, a decisão sequer de qual matéria eles deverão fazer naquele dia. Muitas vezes o repórter inicia seu dia de trabalho ignorando para onde ele será designado e sobre qual fato falará. Isto porque, de maneira geral, os departamentos de telejornalismo são divididos da seguinte forma: há uma equipe de escuta e produção, responsável pela leitura de jornais, escuta de rádio e atendimento de telefonemas da comunidade sugerindo notícias; há equipes de reportagem, constituídas basicamente por um repórter, um cameraman, um operador de áudio e um motorista que chegam, pegam a pauta do dia, veem para onde foram designados, e só voltam depois com a matéria bruta; 
uma equipe de editores, responsável por pegar as matérias brutas e editá-las para que fiquem prontas para aparecer no telejornal; e os editores-chefes, com quem são discutidas as pautas, as reportagens e os cortes nas edições. Essa matéria bruta é composta por um conjunto de imagens, entrevistas e narrações do repórter que chega muitas vezes a ter 30 minutos. Esse material é passado para o editor de matérias, que fará o arranjo do texto e das imagens até que estejam preparados para entrar no telejornal. Geralmente a matéria, quando aparece no telejornal, não excede um minuto e meio, ou seja, a maior parte do material é descartada, seja em função da sua má qualidade para ir ao vídeo, seja em nome da coesão pretendida para a matéria final. Vai para a grade de programação aquilo que é considerado factual. O que não é factual não interessa. Matérias "frias", não factuais, ou fatos cuja importância é considerada menor podem ser retirados da pauta e substituídos por um assunto considerado factual. Essa decisão, evidentemente, cabe sempre ao editor-chefe. Privilegia-se, neste caso, o caráter imediato do fato. No caso do jornalismo impresso, a matéria, uma vez redigida, é enviada para um revisor para que possa ser adaptada de forma a atender às "normas de redação e estilo" do jornal.

Considerar determinado evento um fato ou não é algo que depende muito menos das ocorrências do dia que do contexto de trabalho desses profissionais, isto é, ainda que o termo "fato" possa ser aplicado a qualquer ocorrência, no contexto de trabalho desses profissionais ele tem uma significação bastante específica, ligada, em primeiro lugar, à sua própria rotina de trabalho. Embora o jornalista seja aquele responsável por certa ligação com os eventos do mundo, já que cabe a ele transmiti-los, seu contato com esse mesmo mundo é bastante restrito. O dia a dia de trabalho consiste, basicamente, em chegar à redação, pegar a pauta, sair, realizar a matéria, voltar, passar o material ao editor e, algumas vezes, sair para realizar outra matéria. Dentro da redação, a rotina de trabalho impede que se pense em qualquer outra coisa que não seja a urgência de preparar o material para ser exibido na próxima edição do jornal ou telejornal. O contato que existe entre esses profissionais é, portanto, de caráter técnico. Muitas vezes o tempo de lazer também é compartilhado entre eles. Assim, eles se reúnem depois do trabalho ou nos finais de semana e o assunto, geralmente, gira em torno da própria rotina de trabalho. Além disso, no caso dos telejornais regionais, não são os repórteres ou os editores que decidem os temas relevantes. Isto é feito, em primeiro lugar, pela equipe de escuta e produção. Uma vez que essa equipe toma como base o que é feito pelo rádio e pelos jornais impressos, a tendência principal é de que se gere uma homogeneização da notícia. ${ }^{7}$ Aquelas que fogem dessa homogeneização são as que foram sugeridas pela comunidade 
através de telefonemas. Ou, em alguns casos, os próprios repórteres podem sugerir a matéria. Depois, esses temas serão discutidos com o editor e com os apresentadores do telejornal para que seja fechada uma pauta para o dia seguinte. Quando nada considerado relevante é sugerido, os temas se tornam recorrentes. Conforme depoimento obtido por Travancas (1993:49): "Todo dia é a mesma coisa. De vez em quando 'pinta' uma novidade. Senão, é sempre buraco e passeata. De vez em quando 'pinta' um tiroteio".

Nesse contexto, há eventos ou assuntos que assumem, para a rotina de trabalho do jornalista, uma significação ordinária, ou seja, fazem parte de um cotidiano esperado. Há, em contrapartida, eventos imprevisíveis por si mesmos ou por suas dimensões. Como me disse um jornalista de uma das mais importantes afiliadas da Rede Globo, "se morrerem três pessoas num acidente, isso não vira notícia, mas se morrerem cem...". E também, como observou Travancas (199345): "Reportagens importantes são os acontecimentos imprevistos e de grande porte, que têm mais chance de ir para a página ímpar ou de dar uma primeira página [...]".

Embora o depoimento obtido por Travancas refira-se ao jornalismo impresso, a mesma lógica pode ser observada no telejornalismo. A questão fundamental, contudo, é que, em função dessa rotina, esses eventos adquirem um caráter extraordinário, assumem uma significação extracotidiana. Aqui há duas coisas em jogo. Primeiro, que esses eventos só são considerados factuais quando visíveis, observáveis, ou seja, se não visível, se não observável, a matéria é considerada sem esse caráter factual. Segundo, forçosamente os eventos, para que sejam considerados notícia, precisam ter esse caráter imediato e extraordinário. Com isso, alguns temas, ainda que visíveis, observáveis, perdem seu caráter factual por fazerem parte de uma rotina cotidiana, por não terem esse caráter extracotidiano.

A bibliografia clássica sobre as condições de produção de matérias para o jornalismo tem apontado, nas últimas décadas, os aspectos extraordinários ou espetaculares das notícias. ${ }^{8}$ Quero, no entanto, chamar a atenção para um aspecto sobre o qual, me parece, essa bibliografia não tem tratado e que me foi possível perceber quando da realização de minha etnografia. O repórter assume, nesse contexto, relações diferentes com os assuntos ordinários e os extraordinários que encontram uma tradução seja na linguagem utilizada para narrá-los, seja na edição final da matéria. Os assuntos considerados ordinários são narrados de forma sucinta, tão somente comunicados. Já a relação estabelecida com os assuntos extraordinários é, ao contrário, de outra intensidade. O repórter passa a ter com a notícia uma relação igualmente extraordinária, que se expressa através da seleção de matérias, do uso da imagem e da linguagem utilizadas por ele. Quanto mais extraordinária for 
considerada a notícia, tanto mais intensa será a linguagem utilizada para traduzir esse caráter:

A pior notícia do dia: a nave Challenger explode poucos segundos após decolar. O povo americano viu tudo e até agora não acredita no acidente. A beleza das imagens no céu contrasta com a dor que o mundo está sentindo (Memória Globo 2004:190).

Na narração acima, pode-se perceber uma série de termos ou de períodos que são utilizados para conferir uma maior intensidade ao núcleo da notícia ("a nave Challenger explode poucos segundos após decolar"): "a pior notícia do dia", o povo que viu, mas "até agora não acredita" no acidente, a "beleza das imagens" das pessoas explodindo junto com a nave, a "dor" que o "mundo" está sentindo e o "contraste" que existe apenas enquanto construção narrativa. A linguagem utilizada é intensa, porque é intensa a relação estabelecida entre esses profissionais e os fatos considerados mais extraordinários.

Não é fortuito, portanto, que seja feita a seguinte recomendação, através de memorando, pela diretoria da Central Globo de Jornalismo:

Os telejornais têm que ser vibrantes, precisam ter sempre um bom ritmo. Eles retratam o dia a dia das notícias mais importantes do país e do mundo.

Um bom ritmo se consegue com matérias editadas no tempo certo, texto enxuto e leitura vibrante.

Recomendo a todos vocês - editores e apresentadores - o maior empenho para que os nossos telejornais estejam sempre no ritmo correto. E lembro que o diálogo permanente entre quem escreve e quem lê é o melhor caminho para que se tenha um bom resultado no ar (ibidem:152).

A dimensão dos fatos e a intensidade da linguagem caminham, portanto, juntas. Mas essa não é, como pode parecer, uma relação apenas ocasional, com estrita dependência das circunstâncias. Em diversos momentos, a seleção de eventos cuja significação é extracotidiana pode não definir a matéria como um todo, mas definir ou cumprir papel fundamental na pesquisa para outra matéria ou entrevista, como no exemplo a seguir:

A pesquisa não pode ficar por conta da produção porque é a sua experiência de entrevista que vai servir de base para saber o que rende e o que não rende. Para entrevistar a Dercy Gonçalves, por exemplo, fiz uma pesquisa - que começava em jornais de 1928 - e encontrei, em uma matéria feita entre os anos 60 e 70, que ela havia ganho na loteria esportiva quatorze vezes, tendo, 
inclusive, comprado um apartamento com um dos prêmios. Usei isso, então, na entrevista. É sempre curioso destacar fatos que as pessoas desconhecem ou dos quais já esqueceram (Correia 1994:58).

Não é fortuito, assim, que na sua reconstituição da entrevista e do trabalho de pesquisa para a mesma, a jornalista tenha escolhido justamente aquele detalhe cujo caráter é extraordinário para reconstituir sua memória do fato. Isto pode ser observado também em outros depoimentos.

A escolha de eventos "avançados", "ousados", "completamente diferentes", "fora da realidade" e de grandes dimensões é uma forma de conferir um caráter extraordinário à rotina ordinária do trabalho cotidiano. Mas não só. É também, principalmente, uma forma de marcar uma relação específica com a realidade, que se pauta pela ligação refeita no dia a dia com o extraordinário. Sendo assim, se tomarmos como base o livro publicado pela Rede Globo contando a história de seu principal telejornal, o Jornal Nacional, veremos que na lista de "grandes" reportagens figuram "grandes tragédias", incêndios, desastres aéreos e casos "que se tornaram referências da crônica policial por detalhes violentos ou tramas surpreendentes" (Memória Globo, 2004:144).9

A linguagem utilizada não é o único recurso para traduzir a relação extraordinária estabelecida com os eventos. A hierarquia que conduz da produção local de notícias à sua exibição em rede nacional também o é. Com isso, os fatos que possuem uma dimensão local, uma vez a relação estabelecida com eles sendo de caráter extraordinário, passam a adquirir proporções que não podem ser mensuradas, transformados em assunto nacional ou, às vezes, internacional, como no exemplo abaixo:

Uma das coberturas de destaque dos primeiros anos do JN [Jornal Nacional] foi a do desabamento do elevado Paulo de Frontin, no Rio de Janeiro, no dia 20 de novembro de 1971. Vinte mil toneladas de concreto caíram de três vãos do elevado sobre 48 pessoas, vinte carros, um ônibus e um caminhão que estavam parados num sinal de trânsito. Poucas horas depois, edições extraordinárias do Jornal Nacional mostravam a milhões de telespectadores a dimensão do fato através das imagens cruas do desespero de amigos e parentes das vítimas.

Glória Maria, uma das repórteres a cobrir o acidente, conta como foi: "Era um sábado e nós estávamos saindo para almoçar, por volta de uma e meia da tarde. O telefone tocou, e alguém avisou que o elevado caíra. Pensei que fosse brincadeira. Mas era preciso apurar. Telefonamos para moradores das redondezas e confirmamos o acidente. Fomos para lá e, pouco depois, chegou uma unidade móvel da Globo". 
Na emissora, as primeiras informações foram lidas por Sônia Maria, apresentadora do Jornal Hoje. Pouco depois, Cid Moreira, como apresentador do Jornal Nacional, chegou e assumiu o posto. Até às 16h, ainda não havia imagens da tragédia. Quando começou a chegar, o próprio Armando Nogueira [então diretor do Departamento de Jornalismo da Rede Globo] ajudou a editá-las na moviola, enquanto o editor Edson Ribeiro preparava os textos. No local do desabamento, ao mesmo tempo em que Sabá, de um helicóptero, registrava as cenas, uma tinturaria e uma mercearia foram transformadas em minicentrais de televisão, de onde os repórteres informavam sobre o trabalho de resgate dos corpos. Naquela noite, o $J N$ foi todo dedicado ao assunto. Por sua dimensão, o fato local se transformou em comoção nacional (ibidem:39).

Neste caso, à semelhança do depoimento anterior, o que está em jogo é muito mais a descrição do trabalho empreendido pelos profissionais do que a do fato noticiado por si mesmo. Isto porque tanto o fato quanto o trabalho são narrados de forma a estabelecer uma equivalência de significações entre um e outro. A linguagem utilizada para narrar o fato demonstra a intensidade da relação que teve com aqueles profissionais. Contudo, a mesma relação intensa na narração do fato pode ser observada na exposição dos detalhes do trabalho executado para a sua transmissão. Ela é feita de forma a deixar uma impressão forte do trabalho do dia a dia. Assim, "o próprio Armando Nogueira ajudou" a editar as imagens na moviola, enquanto um helicóptero registrava as cenas ao mesmo tempo em que dois estabelecimentos comerciais locais foram transformados em minicentrais de televisão. A linguagem, portanto, não expressa apenas a intensidade da relação que esses profissionais estabelecem com os fatos, mas também o seu esforço para tentar imprimir uma significação maior à própria rotina de trabalho.

Outro exemplo igualmente significativo nesse mesmo sentido é a descrição de como foi feito, na televisão, um dos debates para as eleições presidenciais:

Dois dias antes do segundo turno das eleições, em 25 de outubro, a Rede Globo realizou o último debate entre os dois candidatos. O modelo do encontro foi inspirado no debate final que se costuma realizar nas campanhas presidenciais norte-americanas $[\ldots]$.

Do debate americano, três coisas foram aproveitadas: a arena, a possibilidade de os candidatos se movimentarem livremente e a plateia que fazia perguntas $[\ldots]$.

Como previsto, os dois candidatos se movimentaram livremente pela arena, e seus movimentos foram captados várias vezes pelas câmeras. Assim, enquanto 
Serra falava, Lula poderia se aproximar bem dele para encará-lo ou vice-versa. No fim do debate, os dois candidatos deram entrevistas coletivas e fizeram questão de dizer que o modelo era vitorioso e que dificilmente, depois daquele evento, outro tipo de debate poderia ser tentado (ibidem:366-367).

Ao se supor que "dificilmente, depois daquele evento, outro tipo de debate poderia ser tentado", o próprio trabalho é transformado em fato extraordinário. Como se a partir dele um novo presente tivesse início: antes era de um jeito, agora é de outro. Contudo, um detalhe marcante pode ser observado aqui. Ao transformar o próprio trabalho em fato extraordinário, o jornalista deixa de ser apenas uma testemunha e passa a assumir o caráter de protagonista dos eventos. Creio que seja essa indissociação criada entre a importância do evento e a importância de quem o narra, entre a protagonização do evento e a protagonização de sua comunicação, entre autoria e narração, que pode explicar (entre outras características, que pretendo discutir a seguir), a meu ver, a suposição de que a "memória da imprensa" e a "memória nacional" sejam uma única e mesma coisa.

É apenas nesse contexto, nesse esforço realizado diariamente para imprimir um caráter extraordinário ao cotidiano de trabalho e de crença numa indissociação entre a importância dos eventos e a importância de quem os narra, que podem ser compreendidos o conteúdo e a inversão feita por um livro bastante citado aqui, no seu subtítulo, organizado para contar a história do Jornal Nacional (Memória Globo). Nele, não é a história que é transformada em notícia, mas o contrário: "a notícia faz história".

A ênfase no caráter extraordinário da notícia e do próprio trabalho jornalístico tende, com isso, a apagar os aspectos ligados à sua rotina diária: a obrigação de corresponder a pautas predefinidas; a necessidade de cumprir certas metas para o perfeito preenchimento da edição do jornal ou telejornal; a adequação da escrita ou da fala a certas exigências e normas estilísticas bastante rígidas; a cobrança de agilidade na elaboração dos textos; a preocupação para se evitar um tom demasiadamente "intelectualizado" ou "rebuscado" na transmissão de informações que necessitam ser curtas; o fato de que boa parte do trabalho desses profissionais pode ser inutilizado, excluído das pautas; a comunicação diária dos acontecimentos na forma de um "relatório", cuja característica principal é a isenção do ponto de vista de seu autor (apenas os editores e os articulistas podem expressar sua opinião e estão desobrigados da elaboração desses "relatórios" diários) etc. Ou seja, apagam-se todas as características que o trabalho jornalístico possa ter de "burocrático". Não é fortuito, desta forma, que a definição mais amplamente aceita para o jornalista — e pelos jornalistas — seja a do repórter, embora 
seu número nas redações seja cada vez menor. Trata-se de uma definição que tende a apagar ou ocultar a maior parte das funções - burocráticas e, por isso mesmo, menos valorizadas - que definem a rotina do trabalho jornalístico. ${ }^{10}$

\section{Memória jornalística e memória nacional}

Sabemos que a definição "clássica" para o jornalismo é aquela relativa à reportagem. Sobre essa definição incidem dois aspectos que merecem atenção: o trabalho de reportagem em si e a escrita da notícia ou matéria. "Eu queria dizer, antes de mais nada, que um dos alimentos da alma do repórter é o 'espírito de aventura' [...]" (Faerman 1998:151).

Este trecho faz parte de uma série de depoimentos de jornalistas convidados a expor o que pensam a respeito de si e de sua profissão. Apesar da simplicidade - ou economia - em sua formulação, ele toca em aspectos fundamentais da forma como os jornalistas pensam - ou "representam" - a realidade na qual estão inseridos e a sua maneira particular de inserção nessa realidade. A "alma do repórter" e o "espírito de aventura" traduzem a suposição não apenas de uma essência que caracteriza o exercício da profissão, mas também que só se chega a essa essência através de uma experiência particular, essa "aventura". Mas há diferenças significativas que podem ser observadas em função tanto da geração à qual pertence o repórter quanto dos modos como o trabalho jornalístico é dividido, através das funções de cada um e de sua posição na hierarquia. As definições abaixo e mais adiante referem-se estritamente ao repórter e à reportagem:

Numa noite abafada de 1963, abriram-me uma porta que dava acesso a uma câmara de horrores, no Hospital Psiquiátrico do Juqueri, nos arredores de São Paulo. [...] Fazia uma semana que eu percorria os pátios do Juqueri, recolhendo as imagens da miséria humana que se escondia atrás de seus altos muros [...] Só quando me vi fora do pavilhão, engolindo avidamente o ar puro da noite, pude entender por que, antes de abrir a porta, o homem da clínica havia me perguntado:

— O senhor tem coragem para ver? (Dantas 1998:19-20).

O encadeamento das frases segue uma ordem que se repete em vários depoimentos de jornalistas. A linguagem expressa uma experiência de choque, mas também, principalmente, de descoberta. O encadeamento das frases traduz uma relação de descoberta que consiste num lento caminhar 
em direção a um fato cuja significação está na suposta verdade que ele encerra. É como se fosse o "mito da caverna" na sua versão contemporânea. O homem sai das sombras nas quais vive e caminha em direção à luz. Contudo, há diferenças significativas entre o mito da caverna e os depoimentos dos jornalistas. Em Platão, luz e sombra são imagens figurativas. Para se chegar à verdade, o homem deve se libertar das aparências das coisas. A percepção sensível que se tem do mundo pode conduzir não à sua verdade, mas à sua ilusão. Deve-se, portanto, abandonar as ideias formadas pela percepção sensível para então se chegar à essência real e verdadeira das coisas.

Nas narrativas dos jornalistas a relação entre luz e sombra é radicalmente diferente. A ordem das frases traduz uma experiência de descoberta que consiste exatamente na percepção sensível das coisas. O lento caminhar em direção à luz, a uma realidade tida como mais profunda, real e verdadeira, não se baseia num abandono da percepção sensível. Ao contrário, a realidade à qual se chega é formada, concebida somente a partir das impressões individuais do sujeito que narra, o repórter.

Os movimentos realizados no espaço fundem-se aos movimentos realizados na consciência. Assim, o universo descrito é o reflexo da consciência do narrador. Através da linguagem, o indivíduo estabelece uma unidade entre sua ação, os movimentos feitos na sua consciência, e uma realidade entendida como mais profunda e genuína. A ordem das frases vista no trecho acima é a mesma que pode ser observada em vários outros depoimentos: 0 indivíduo sai de uma posição de dúvida e caminha em direção a um fato, a um documento, a uma informação e, nesse caminhar, a realidade vai se tornando cada vez mais clara, até chegar a um ponto máximo, no qual a dúvida inicial não mais existe, e assim a realidade assume todos os seus contornos. A linguagem utilizada, através de uma ordem bastante específica de frases, expressa a tentativa de esquadrinhar essa realidade mais profunda, mais genuína, à qual só se pode chegar através da experiência pessoal, pois é ela que permite a ligação com esse caráter mais real. Só o jornalista, e mais especificamente o repórter, na sua ação, é que pode fundir a realidade objetiva à sua consciência e, assim, constituir uma realidade mais profunda. Ou, para utilizar o termo que mais se repete nos depoimentos, uma "verdade".

É essa ação, vivida como uma experiência individual, a característica mais enfatizada nos depoimentos dos repórteres a respeito de sua própria profissão:

Coragem para ver é uma das exigências do ofício de repórter. A esta deve acrescentar-se outra, igualmente importante - a coragem de contar o que se vê. [...] Só seguindo em frente, sem se deter na busca da informação, dos fatos, 
da história da reportagem, o repórter pode deixar o medo para trás. Nesse caminhar, muitas vezes ele se surpreende: "Diabos, como é que eu fui me meter nesta!" (Dantas 1998:20-21).

Cumpre chamar a atenção para um aspecto geral e importante que pode ser observado nesses depoimentos: eles permitem, ou viabilizam, a conversão da "trajetória profissional" em capital simbólico. Não importa qual seja essa trajetória, assim como não importa a geração à qual pertence o jornalista, ela sempre é utilizada como "prova" simbólica de seu valor profissional. O "bom jornalista" é aquele que "muito viu" e "muito fez", portanto, aquele que tem "muito a contar". É através da narrativa biográfica — cuja história de vida consiste, basicamente, na história profissional ou nos eventos que a ela conduziram - que o "muito visto" e o "muito feito" passam a expressar o mais alto valor simbólico que uma trajetória, nesse contexto, possa ter.

Contudo, a reportagem não ocupa lugar central apenas na definição da profissão, ocupa também um lugar muito particular na relação entre a chamada memória individual e a memória coletiva. Por um lado, é a narrativa de um indivíduo em particular, o repórter, cuja narração se baseia, em grande medida, em sua própria história ou, muitas vezes, naquilo que é transmitido por seus "contatos". Ela é escrita, na maior parte das vezes, na forma de um "testemunho", uma vez que depende da "presença" do repórter, seja na pesquisa para a matéria, seja no próprio acontecimento. Por outro, refere-se a eventos cuja importância vai além do próprio indivíduo e que, desta forma, são considerados "coletivos", "sociais". A reportagem faz da história pessoal uma história coletiva, ou vice-versa. Ela se inscreve, assim, nessa linha de fronteira entre o individual e o coletivo e, ao mesmo tempo, deve todo o seu significado a essa posição forçosamente ambígua. Fora dessa posição, talvez não pudéssemos falar de "reportagens". Além disso, não se pode perder de vista que, por mais pessoal que possa ser um dado registro jornalístico, ele é sempre reproduzido em grande escala, assumindo, posteriormente, o valor de "documento" não apenas pessoal, mas também histórico, coletivo:

Mas a grande questão é saber: a quem cabe ser guardião da memória de uma coletividade? Quem detém autoridade para realizar o trabalho de seleção e enquadramento do passado de um grupo? [...].

Os meios de comunicação não são os únicos, mas são, hoje, um dos principais atores na realização do trabalho de enquadramento sobre o passado das coletividades. É através deles que se realiza a operação da memória sob os acontecimentos e as interpretações do passado que se quer salvaguardar. $\mathrm{O}$ 
controle da memória social parte de "testemunhas autorizadas" e o jornalista, mediador entre o fato e o leitor, interfere nesse processo, não só enquadrando os fatos, mas reconstruindo valores e identidades no controle da realidade (Ribeiro \& Brasiliense 2006:4).

Essa posição singular e ambígua, fronteira entre uma memória individual e uma coletiva, confere características específicas à notícia e à reportagem enquanto "fontes" que precisam ser mais bem exploradas e compreendidas. Antes de mais nada, cumpre lembrar que a escrita ou a narração garante a "presença" do jornalista num dado momento ou acontecimento histórico:

O jornalista é, antes de tudo, um repórter. Cabe-lhe a árdua tarefa de sair em busca da notícia fresca, da entrevista inédita, do acidente que acabou de ocorrer, da pesquisa que ainda será divulgada. Reconstruindo os novos acontecimentos e registrando opiniões e depoimentos relevantes, escreve a história imediata, mantendo os leitores atualizados e legando aos autores da historiografia de longo prazo fontes informativas de valor inquestionável (Alquéres 2005:11).

Isto permite ao jornalista e ao jornal partilharem a importância que um dado acontecimento possa ter, fazendo coincidir essa "importância histórica", seu "registro" e, com ele, a "presença" — na história — do jornal ou do jornalista. Portanto, a escrita possibilita o encontro entre a "memória" e sua "prova documental": lembrar-se - no caso do jornalismo e diante do fato de que as reportagens são "documentos" que ocupam essa posição singular e ambígua - é encontrar não um acontecimento no passado, mas a narrativa desse acontecimento no passado. Com isso, a relação de dependência do acontecido ao narrado torna a narrativa o documento mais importante de todos. É essa relação de dependência que pode explicar, a meu ver, aquelas definições da profissão que se apoiam principalmente no trabalho da escrita, e não no da reportagem tão somente, e que fazem do jornalista o "guardião da língua, da escrita e da credibilidade histórica" (Sodré 2008:54). No caso desta última definição, essa dupla memória, individual e coletiva, compreende não só o acontecimento histórico (verídico, fidedigno), mas também a língua e a escrita. A importância "documental" do jornalismo oscila, com isso, ora em direção ao trabalho de reportagem, ora em direção à escrita (ou, por vezes, em direção a outras formas de registro, como a fotografia ou o documentário, por exemplo).

Mas não nos enganemos: se, teoricamente, qualquer notícia ou reportagem pode ter valor como "documento histórico", na prática nem todas elas têm esse valor. Algumas dessas notícias e reportagens, e apenas algumas, 
sobrevivem em função de uma série de escolhas. ${ }^{11}$ A notícia diária, assim como a conhecemos e vemos todos os dias, é feita com a preocupação de ser lida ou vista "naquele dia". No entanto, algumas delas tornam-se fonte permanente de consulta, passando a ser relidas ou revistas. Há, com isso, uma tensão - que ainda está por ser mais bem compreendida - entre o lido (ou visto) e o relido (ou revisto), entre a notícia e seu valor históricodocumental, entre o que não precisa e o que deve ser - sempre ou oportunamente - relembrado. É essa tensão que, a meu ver, traduz ou informa a balança das relações de poder no jornalismo, assim como as oscilações dessa balança ao longo do tempo.

A desigualdade que pode ser observada nos critérios de escolha entre o que não precisa e o que deve — ou merece — ser revisto ou relembrado é homóloga à desigualdade entre as matérias ordinárias e as extraordinárias, assim como à desigualdade de usos da linguagem na transmissão dessas diferentes notícias, mas principalmente é homóloga à desigualdade observada entre as posições mais autônomas e as mais dependentes no interior do jornalismo. É a mesma desigualdade observada na diferença entre as matérias e as notícias assinadas e as não assinadas, entre aquelas cujo autor tem um nome próprio e as demais, cuja autoria é "da redação".

Essa desigualdade se traduz em notícias e informes para serem lidos ou vistos "naquele dia", tão somente, e em reportagens, crônicas e editoriais para serem relidos ou revistos, considerados fonte de informação sobre - e para a própria profissão. É esse material que sobrevive, resultado das tensões diárias presentes no interior da profissão, que propriamente constitui aquilo que é entendido como a "memória do jornalismo". A homologia entre essa "memória" e as notícias quentes, as assinadas e aquelas mais autorais faz com que ela corresponda a um afastamento — ou a um "esquecimento", diria Ricoeur (2007) — de tudo aquilo que lembre a rotina — burocrática — em que se inserem as posições mais baixas, ou mais dependentes, da profissão. ${ }^{12}$

Trata-se, portanto, de uma memória ou de uma história - assim como de um "esquecimento" - que age sobre o presente antes de agir sobre o passado, que atinge os próprios jornalistas desigualmente, uma vez que reproduz seus critérios de hierarquização ao reproduzir as linguagens de suas posições dominantes ou mais autônomas: o editorial, a reportagem "investigativa", o comentário profissional, a crônica, a crítica, a matéria "assinada" etc. Talvez isto nos permita compreender melhor porque a definição "clássica" para o jornalismo oscila ora em direção à reportagem, atividade entendida como "autoral", ora em direção à escrita — nas suas formas mais autônomas, evidentemente. Permite também entender melhor porque a rotina diária para o exercício da profissão se define por meio de um controle rigoroso sobre a 
escrita, assim como sobre a reportagem, ${ }^{13}$ controle este que é tanto maior quanto mais se dirige às suas posições mais baixas e dependentes. ${ }^{14}$

\section{As trajetórias exemplares}

A memória e a história pensadas pelo jornalismo não dependem apenas das tensões observadas em sua rotina diária de trabalho e da posição singular e ambígua, fronteira entre uma memória — ou uma escrita — individual e uma coletiva, que caracterizam a notícia e a reportagem. A exigência do diploma para o exercício da profissão, de 1969 a 2009, foi capaz de promover mudanças significativas no mercado de trabalho desses profissionais, assim como de gerar tensões até então inexistentes. Entre essas tensões está a concorrência pelas posições de maior autoridade e autonomia na profissão. Trata-se de uma concorrência cujo efeito imediato não é tão somente a mudança nos critérios de acesso às posições de maior prestígio, mas também a própria definição daquelas trajetórias consideradas "exemplares", as quais devem ser sempre lembradas e têm valor de "modelo" para pensar a profissão e sua história, e daquelas de menor importância, mais burocráticas, as quais não devem ser lembradas e não são "exemplares" na definição da profissão e de sua história.

O conflito passou a ser definido, nos anos 80 e 90, por "antigos" e "novos" jornalistas — os "antigos" sendo os profissionais mais "críticos", e os novos, egressos dos cursos de Jornalismo, os mais "acríticos". Os primeiros autodefiniam sua posição como de enfrentamento do poder político e econômico, e os segundos eram definidos — por esses mais "antigos" como alienados. É expressivo disto que o trabalho de Travancas (1993), por exemplo, dedique parte substancial de suas observações à oposição entre "antigos" e "jovens" profissionais e destaque, no capítulo referente aos "jovens", depoimentos que exemplificam o caráter "apolítico" ou "mercadológico" dessa nova geração:

Minha função de chefia é mandar os repórteres para a rua cobrirem os fatos. Não comungo com a ideologia da empresa, mas sou parte da engrenagem. E é fácil conviver com isso. Eu alugo minha força de trabalho, não minha cabeça. E é assim em todos os jornais. Não me firo, nem prejudico ninguém. Procuro fazer o meu trabalho o melhor possível (Travancas 1993:94).

Há dois aspectos muito importantes envolvidos nessa mudança. De um lado, a maneira como ela foi vivenciada por "antigos" e "novos" jornalistas, 
o que ela representava para ambos e, principalmente, para a definição da própria profissão que parecia estar em jogo. De outro, a redefinição das funções e do mercado de trabalho que passava por uma visível reorganização. O depoimento abaixo é, me parece, um dos mais expressivos indicadores das mudanças ocorridas em função da exigência do diploma para o exercício da profissão. Seu significado fica mais claro quando comparado com os de outros jornalistas em momentos diferentes da história do jornalismo:

No Estadão dos anos 60, cada repórter, e eram mais de trinta só na reportagem geral, tinha que ter suas fontes, ser seu próprio pauteiro, caçar notícia, como se dizia. Precisava ficar aberto à informação trinta horas por dia, como os bancos eletrônicos, e ajudar na edição e na pauta do dia seguinte. E, depois, muitos ainda esperavam o jornal rodar na oficina para conferir se não havia saído alguma coisa errada. Repórter que era repórter não ia para casa ou para o bar sem levar o jornal ainda quente debaixo do braço.

Fora os setoristas, que já saíam de casa sabendo para onde ir e o que fazer, os demais tinham mesmo era que matar um leão por dia, sem saber onde. Primeiro, claro, era preciso achá-lo - se possível, antes da concorrência.

Como não tinham inventado os filhos da pauta, todo mundo, do porteiro da redação ao motorista da reportagem, passando pelos donos do jornal, perseguia um negócio chamado "furo", a notícia quente, exclusiva, inédita, o fato que ninguém havia descoberto antes.

Quando você vai hoje a uma redação, pode achar que errou de endereço e entrou por engano numa repartição pública. Encontra lá cada um quietinho diante do seu terminal, cumprindo uma função determinada pelo manual, burocraticamente. Se alguém falar um pouco mais alto ou der uma risada, já é logo estigmatizado como maluco.

Se trouxer uma informação não prevista na pauta, então, uma novidade sobre a qual ninguém está falando, corre o sério risco de ser deletado no próximo passarralho (o falo voador que, vira e mexe, pousa nas redações). Só os telefones ainda funcionam freneticamente. Se eles saírem do ar, corre-se o risco de não ter jornal no dia seguinte. Como a maioria do povo não tem telefone, fica fora da pauta.

Dessa forma, construíram-se ao longo dos últimos anos algumas carreiras coroadas na nossa imprensa só por telefone, sem que se tenha registro de algum furo ou reportagem exclusiva cometidos por seus proprietários. Sem passarem pela reportagem, pularam diretamente da academia para cargos de chefia, determinando os rumos do new journalism tupiniquim nos anos 80. Nada de comer poeira e sujar os sapatos para conhecer pessoalmente a realidade em que vive o chamado povo brasileiro. Por isso, tantos idolatram os professores doutores, as teses, as teorias, até por falta de prática (Kotscho 1998:187). 
Esse conflito ganha, nos anos 80, contornos claramente definidos, opondo parte da imprensa, capitaneada pelo jornal Folha de Sáo Paulo, e os cursos de Comunicação Social. A expressão "filhos da pauta" passou a ser utilizada, dentro do jornalismo, para designar essa geração mais nova de profissionais que se caracteriza, com base na definição que os próprios jornalistas lhes atribuem, pela sua formação universitária e pelo seu ingresso, logo após a conclusão do curso, na carreira. São os jornalistas mais antigos que usam a expressão para designar esses novos jornalistas.

As explicações mais correntes para o conflito que é claramente manifestado no uso da expressão "filhos da pauta" dizem respeito ora a um conflito de gerações, ora a uma diferença relativa às novas tecnologias e aos meios de trabalho anteriormente utilizados por esses profissionais. Mas a expressão diz respeito, mais especificamente, à acusação que recai, muitas vezes, sobre esses novos jornalistas de alienação, de falta de crítica ou de passividade diante das mais diversas formas de poder. Dentre elas, aquela representada pelo próprio jornal. A principal acusação, com isso, é a de ausência, nesses profissionais, do capital simbólico próprio ao jornalismo: o "muito feito" e o "muito visto". As críticas aos cursos de Comunicação ressaltam essa "ausência de capital simbólico" de duas formas diferentes: ora referindo-se à sua "deficiência técnica", ora à sua "deficiência na formação crítica dos profissionais". "Deficiência", neste caso, é o termo utilizado para alegar falta de experiência e, com isso, "ausência de uma trajetória, de uma história". Isto pode ser observado nos depoimentos já nos anos 80 e início dos anos 90. Era com surpresa, por exemplo, que certos profissionais eram recebidos quando falavam das "capacidades dos egressos":

Embora a maioria dos mais experientes - e pode-se dizer competentes - jornalistas do país se negue a ver algo positivo nos egressos das universidades e isso ficou claro no debate encampado pela Folha de São Paulo pelo fim da exigência do diploma para o exercício da profissão desde a última Constituição eles são diferentes. São mais criativos, inquietos e dispostos. Três características que acabam compensando as deficiências técnicas dos cursos (Silveira 1992:208).

Apesar da acusação de "deficiência" persistir, há, contudo, uma diferença significativa entre a maneira como os egressos dos cursos de Jornalismo eram citados nos anos 80 e início dos anos 90 e como eles são citados no depoimento de Kotscho, já do final dos anos 90. Nos anos 80 esses egressos dos cursos de Jornalismo não representavam uma ameaça. Eles preenchiam diversas funções técnicas - subordinadas - e, nelas, podiam ser vistos 
com bons olhos até pelos mais "experientes". Já no depoimento de Kotscho, mais recente, eles passaram a representar uma evidente ameaça. Posições de comando, que antes eram ocupadas pelos mais "experientes", passaram a ser ocupadas por esses egressos aos quais os mais antigos na profissão, como fica claro no caso de Kotscho, precisam se submeter. O que esses depoimentos evidenciam é uma significativa mudança nas relações de poder no interior do jornalismo.

Mas a agressividade de seu depoimento não se dirige apenas àqueles jornalistas egressos dos cursos de Jornalismo, dirige-se também à "pauta". A "pauta" expressa, a um só tempo, a imposição de uma rotina para o trabalho no jornalismo e de uma "forma" para esse mesmo trabalho. É ela que direciona os trabalhos de execução das matérias, assim como define sua ordem de importância e de apresentação. Ao longo das últimas décadas, o jornal foi mudando gradativamente de forma, assim como também se modificou a representação do que é o próprio "jornalista". A definição clássica do jornalista — que ia antes para a rua, para colher informações ou correr atrás dos fatos, depois para a redação, onde o que havia sido observado na rua era transformado em notícia, e só depois do jornal pronto, recém-saído da gráfica, é que ia para casa — tem sido gradativamente substituída pela imagem do profissional que cumpre uma pauta de reportagem previamente definida, a exemplo de uma atividade burocrática como qualquer outra. Isto demonstra que, embora ainda considerada a essência mesma da profissão, a reportagem teve seu status e seu peso, no interior do jornalismo, profundamente modificados, a tal ponto de ser cada vez mais associada à memória e à história da profissão.

O debate entre "antigos" e "novos", "críticos" e "acríticos" traduz uma reorganização mais geral e profunda no mercado de trabalho desses jornalistas, ou seja, o conflito que antes poderia ser definido pela presença ou a ausência de um capital simbólico próprio ao jornalismo (a trajetória, a história, o "muito visto" e o "muito feito") passa a adquirir novos contornos, desta vez entre dois capitais simbólicos diferentes: de um lado, o capital representado pela trajetória profissional e, de outro, o possível capital representado pela formação universitária. ${ }^{15}$

A exigência do diploma mudou gradativamente o mercado de trabalho desses profissionais. Primeiro, transformou o interior das redações. As novas gerações de jornalistas eram formadas por egressos do ensino universitário da profissão. Não foi à toa, portanto, que essa mudança foi vivenciada e sentida pelos profissionais daquele momento, anos 80 e 90, como um "conflito geracional".

Segundo, aqueles dotados de um "saber técnico" para a profissão eram os que ocupavam seus degraus mais baixos. O diploma tornou possí- 
vel a esses egressos dos cursos de Jornalismo, compreendidos muito mais como técnicos do que como jornalistas pelos profissionais mais antigos e consagrados na época, uma "mobilidade ascendente" na profissão, isto é, possibilitou que os cargos de decisão, aqueles de maior prestígio, autoridade e autonomia, fossem ocupados por esses egressos. No entanto, essa "mobilidade" era pautada em critérios - o diploma e o saber universitário estranhos ao jornalismo então consagrado. Não é à toa que o conflito era também sentido e vivenciado como se fosse entre "críticos" e "acríticos". Todos aqueles antes destinados às posições de menor prestígio, aquelas consideradas mais burocráticas e que nunca contaram para a construção da identidade do jornalismo, agora também estavam destinados às posições de maior autoridade e autonomia.

Terceiro, o horizonte de trabalho desses novos profissionais é diferente do horizonte daqueles jornalistas mais "antigos". A exigência do diploma fez com que surgisse, ao longo desses anos, um número considerável de novos cursos universitários habilitados a formar jornalistas. Com isso, o ensino e a pesquisa tornaram-se opções estáveis de trabalho e de carreira para muitos desses profissionais, sendo que sobre essas carreiras recaem os critérios de promoção e reconhecimentos próprios à academia. ${ }^{16}$ Além da diferença anteriormente existente entre os mais e os menos "experientes" na hierarquia das funções da redação, o mercado de trabalho aberto pelas Universidades permitiu que uma nova hierarquia se estabelecesse, desta vez entre os mais e os menos "titulados".

Quarto, as mudanças observadas no mercado de trabalho dos jornalistas tiveram - e têm - forte peso na seleção e na definição da memória e, com isso, nas trajetórias consideradas "exemplares" na história da profissão. A "memória" de uma imprensa cujos momentos de maior brilho e honra estavam ligados à crítica e ao enfrentamento das formas de poder estabelecidas vem gradativamente se alargando de maneira a incluir outros personagens, alguns mais desconhecidos, outros, pelos padrões dos mais "antigos", porventura menos ilustres.

Talvez os efeitos dessa redefinição das trajetórias exemplares, da memória e da história do jornalismo sejam mais bem compreendidos se compararmos duas importantes obras de referência sobre o tema. Creio que um dos trabalhos mais emblemáticos desse contexto de mudanças seja o de Bernardo Kucinski, Jornalistas e revolucionários: nos tempos da imprensa alternativa, publicado pela Edusp em 1991 e republicado, em nova versão revista e ampliada, em 2003. Resgate de uma série de trajetórias exemplares na luta contra o Regime Militar e no seu enfrentamento pelos profissionais da imprensa, a obra tem valor inestimável e inquestionável ${ }^{17}$ e é resultado 
de uma tese de doutorado defendida em 1991 junto à ECA, momento em que o conflito entre "antigos" e "novos", "críticos" e "acríticos" estava em seu auge. A obra alia o "prestígio jornalístico", tanto da trajetória do autor quanto das demais trajetórias tratadas em seu livro, e o "prestígio acadêmico", assim como a tão cobrada imparcialidade do jornalista e a objetividade do cientista ou historiador, ao falar de si mesmo em terceira pessoa, como se autor e personagem fossem dois, e não um: "Os leitores irão estranhar as referências que faço a mim mesmo, como se fosse um segundo eu. Foi a forma que encontrei para não ter que usar a primeira pessoa. Vício de jornalista" (Kucinski 2003:10).

Trata-se também de um importante resgate das posições mais "autônomas" e "legítimas" do jornalismo num contexto de claro conflito entre duas diferentes formas de capitais: o jornalístico, representado pelas "trajetórias exemplares" de um jornalismo crítico e engajado, e o acadêmico, representado pelo "diploma de graduação", condição exigida para o exercício da profissão:

Para fazer esta história, entrevistei cerca de sessenta protagonistas da imprensa alternativa, incluindo muitos de seus líderes, consultei arquivos pessoais e públicos e as coleções dos jornais. Adotei como critérios de inclusão no universo da imprensa alternativa, além do discurso alternativo, a quantidade de trabalho jornalístico agregado e o grau de autonomia jornalística. Por esses critérios, não foram incluídos boletins reproduzidos artesanalmente e em tiragens diminutas por movimentos sociais e comunidades eclesiais de base, e nem órgãos oficiais de partidos políticos e outras instituições da sociedade civil, exceto alguns jornais estudantis. Também não foram incluídos empreendimentos com objetivos predominantemente mercantis (ibidem:9).

Além do mais, há outra tensão embutida na obra que me parece relevante: entre o que deve ser lido (ou visto) e o que deve ser relido (ou revisto), entre o que não precisa e o que deve ser relembrado. O livro, diferentemente da notícia ordinária, escrita para ser lida (ou vista) "naquele dia", é escrito com o claro objetivo de ser relido, de ser fonte permanente de consulta. E disto é igualmente expressivo que um número cada vez maior de "grandes reportagens" seja publicado na forma de livro por iniciativa de diferentes e importantes editoras.

O segundo trabalho, igualmente emblemático, é bem mais recente. Resultado de um esforço articulado entre a Redealcar/Rede Alfredo de Carvalho ("destinada a resgatar a memória e a construir a história da imprensa no Brasil"), a Revista Imprensa, a Universidade Metodista de São Paulo 
e a Editora da Imprensa Oficial do Estado de São Paulo, a obra Imprensa brasileira: personagens que fizeram história, lançada até o momento em três volumes, em 2005 (os dois primeiros volumes) e 2008 (o terceiro volume), e coordenada pelo prof. José Marques de Melo, consiste em um "projeto destinado a biografar personalidades que se destacaram na história da mídia brasileira" (Marques de Melo 2005b:8).

Segundo o coordenador do projeto e dos volumes, o motivo para tal empreitada se deve ao fato de que:

[...] as novas gerações de profissionais midiáticos — jornalistas, publicitários, radialistas ou teledifusores - formados pelas nossas universidades mostram escasso conhecimento sobre a trajetória midiática brasileira.

Isso os transforma em reféns involuntários dos gêneros e formatos alienígenas, reproduzindo continuamente modelos oriundos das matrizes geradoras da cultura pós-moderna, quase sempre à margem da nossa realidade. Trata-se de fenômeno determinado pela ignorância em relação aos padrões midiáticos já testados em território nacional, ausentes das lições que tiveram dos seus mestres, tanto na academia quanto na indústria.

Foi precisamente com a intenção de neutralizar essa lacuna cognitiva que tomamos a iniciativa de encetar um novo movimento cultural, buscando ao mesmo tempo preservar a memória da imprensa e construir a história midiática nacional. Nossa meta é desenvolver ações voluntárias e independentes, embora metodologicamente articuladas, no sentido de completar o inventário desencadeado há um século e ao mesmo tempo tecer a malha que dá sentido ao complexo midiático brasileiro (ibidem:8).

A linguagem utilizada para descrever, mais que o projeto, o próprio esforço nele envolvido, é semelhante à linguagem utilizada, no interior das redações, para conferir um caráter extraordinário à rotina diária de trabalho, ainda que alguns dos termos utilizados sejam mais comuns ao ambiente universitário que ao jornalístico. Isto faz do texto um misto de "projeto acadêmico" e "cruzada" contra a ignorância "das novas gerações de profissionais midiáticos".

Os biografados têm em comum o fato de serem "nomes próprios" no interior do jornalismo, em suas mais diversas atividades: são empresários, editores, cronistas, poetas, críticos, cientistas, professores universitários, humoristas, defensores do consumidor etc. Tomados em seu conjunto, eles não traduzem, dada a diversidade dessas atividades, uma "história coletiva". No entanto, também tomados em conjunto, traduzem as funções e as linguagens das posições de maior autoridade e autonomia do jornalismo, independentemente 
das funções desempenhadas. Revelam, portanto, um esforço de organização e de sistematização das funções e das linguagens que melhor traduzem a autonomia das posições de prestígio da profissão, e que por isso mesmo devem ser continuamente lembradas. Uma vez que essas posições se marcam pela conquista do "nome próprio", é coerente que esse esforço de organização e de sistematização se faça em torno de suas "vidas" e da "contribuição" que cada um desses nomes deu para a história do jornalismo. Diferentemente do livro de Kucinski, no qual os "casos exemplares" eram coletivos e giravam em torno de "jornais", aqui os "casos exemplares" são indivíduos.

Mas o que mais chama a atenção é que a escrita desses perfis biográficos - as ações "metodologicamente articuladas" — é de autoria, na sua grande maioria, de egressos dos cursos de Jornalismo com trajetórias as mais diversas em Programas de Pós-Graduação: História, Ciência Política, Sociologia, Letras, Semiótica etc. e, é claro, também em Ciências da Comunicação. Boa parte desses perfis biográficos, 54 até o momento, teve origem no interior desses diversos programas de pós-graduação. Além disso, muitos desses autores eram - ou são - docentes em algum curso de Comunicação, sendo que alguns ocupam cargos de importância, como a coordenação desses mesmos cursos.

Desta forma, boa parte deles ocupa posições num mercado que deve a sua existência à exigência do diploma para o exercício da profissão. São ações que, no seu conjunto, demonstram um esforço de articulação entre o trabalho jornalístico e o trabalho acadêmico, mas, principalmente, indicam a conquista de uma posição autônoma — e de prestígio - em face do próprio jornalismo. Alguns desses biógrafos, poucos, na verdade, ainda não conquistaram a autonomia assegurada pelos títulos e pelo mercado universitário. Contudo, a própria escrita da biografia serve, simbolicamente, para atestar uma maior autonomia intelectual, uma vez que se trata de uma empreitada que se define por certa erudição, em particular a erudição exigida pela área e que consiste no conhecimento aprofundado desses nomes. Mas não se trata apenas de pesquisadores, são em especial mediadores entre dois campos profissionais distintos. Por um lado, evidenciam proximidade com o mundo pesquisado, são jornalistas de formação; por outro, revelam interesse numa produção mais propriamente acadêmica, da qual extraem significado para a vida profissional e intelectual. Sendo assim, têm tanto interesse na elaboração de um registro de valor exemplar para o jornalismo quanto na transmissão de elementos próprios a certa "tradição universitária".

A autonomia e o prestígio representados pelos títulos e pelo mercado universitário possibilitam, por um lado, que se alargue o número de atividades, de funções e de nomes representativos para a história do jornalismo, o que sem 
dúvida tende a ter efeitos sobre a forma como esses profissionais a concebem. Por outro, reproduz as funções e as linguagens de maior autoridade e prestígio do jornalismo, mas funções estas que muitas vezes se afastam daquela que é entendida como a definição "clássica" para a profissão: a reportagem. Não é mais a reportagem, fronteira entre uma memória individual e uma coletiva e principal definidora da profissão, que permite ao jornalismo encontrar-se no passado ao nele se deparar com a sua própria narrativa, mas sim o registro dessas vidas e trajetórias exemplares e de sua passagem pelo jornalismo.

\section{As divisões do trabalho jornalístico}

O primeiro sintoma que tive de que aquele dia seria para mim completamente defasado retratou-se logo na fisionomia do moço, que antes de abrir a porta do carro me olhou de uma maneira esquisita, entre o espanto e o constrangimento, como se eu estivesse nu ou quase. $\mathrm{Nu}$ eu não estava, em absoluto. Havia até caprichado no meu uniforme diário de quando vou à rua: calça branca, mocassins pretos e uma camisa Adidas, presente de Natal que somente agora iria estrear. Como o rapaz, depois do meio espanto e do meio constrangimento, não disse mais nada, embora de vez em quando mexesse no nó da esplêndida gravata, como se alguma coisa estivesse lhe mexendo com os nervos, a coisa ficou por isso mesmo. E só quando o elevador todo de metal tomou a iniciativa de nos deixar no andar da redação, e quando percebi, nela, a fauna engravatada que num ambiente fosforescente manejava máquinas e toda espécie de mágicos engenhos, é que me dei conta da impropriedade dos trajes com que ia ingressar naquele mundo lunar. O que primeiro me surpreendeu foi o quase silêncio ali imperante, só perturbado por um tilintar mais agudo, o estridular de campainhas para mim inlocalizáveis ou pelo dialogar curto e sussurrante entre um jornalista e outro.

Enquanto meu amigo, à maneira de Dante guiando Virgílio pelas delícias do Paraíso, ia me levando de módulo em módulo, me explicando em voz baixa a utilidade de uma ou outra máquina, de um ou outro prodigioso engenho, meu pensamento divagava. Ou melhor, retrocedia no tempo e no espaço. Pus-me a recordar as redações antigas de tanto jornal e tanta revista por onde eu havia passado. E me vieram à lembrança todos os componentes daquele mundo caótico: o teclar incessante e nervoso das máquinas de escrever, a chegada de repórteres suados, as piadas grosseiras, o cafezinho sempre excessivamente açucarado e morno, a intromissão de populares com reclamações e apelos - e lá, entronizado numa espécie de estrado, como um maestro tentando conduzir uma orquestra de malucos em que cada músico tocava seu instrumento na hora 
que lhe convinha —, o pobre e aflito secretário da redação. Era o caos! Um caos que nada tinha a ver com aquele universo asséptico que eu agora estava visitando em trajes pouco recomendáveis, cheio de cuidado para não esbarrar num daqueles engenhos de sensibilidade à flor da pele (ou das teclas) e com meu gesto desastrado desencadear não sei que irremediável catástrofe gráfica.

[...] Já na rua, na porta do jornal, aonde meu amigo me fora levar, perguntei:

— Você tem certeza de que acabei de visitar uma redação de jornal? Que não estou vindo de um laboratório espacial ou de um departamento qualquer de pesquisas genéticas, coisa assim? (Silveira 1998:90-91).

O espanto do jornalista chama a atenção para mudanças fundamentais que ocorreram no jornalismo ao longo dos anos, essencialmente aquelas que dizem respeito à relação dos jornalistas entre si e com o mundo que eles pretendem noticiar. O contraste entre o ambiente de caos das redações anteriores e a ordem asséptica das novas redações indica quais foram as mudanças mais significativas.

O ambiente das antigas redações é descrito como espaço de trabalho, de convívio, diálogo entre profissionais e, principalmente, contato direto, sem intermediações, com a população. Independentemente de as salas de redação corresponderem exatamente a esta descrição, o fato é que ela enfatiza esses aspectos porque são eles que apresentam um maior impacto e um maior caráter de ruptura com as novas redações. A principal mudança pode ser observada nos elementos relativos ao espaço. Nas novas redações as fronteiras entre os profissionais são muito bem definidas. Não pode haver risco de invasão do espaço alheio. As intromissões são permitidas, mas sem que comprometam os limites entre os profissionais.

As redações antigas deveriam ter também seus limites. Mas o tom de surpresa do depoimento atenta para o detalhe de que eles se tornaram muito mais rígidos. A rigidez da sujeição ao espaço que lhes cabe ali dentro obriga esses profissionais a executarem um trabalho essencialmente técnico. A fronteira com o mundo externo, para fora dos limites da redação, talvez seja a maior de todas. A intermediação com o mundo se dá através da técnica e das limitações que ela impõe ao trabalho. Não há mais "a intromissão de populares com reclamações e apelos". O detalhe da roupa usada pelo jornalista é o mais expressivo, dentre todos os outros, de como a fronteira entre a redação e a comunidade é rígida. Ele se prepara para entrar na sala de redação com a mesma roupa que vai à rua. ${ }^{18}$ Não há porque supor uma divisão entre a rua e a redação, espaços que, pela sua descrição, eram interligados e que agora não apresentam mais nenhuma ligação. O silêncio ordenado da sala e a fauna de engravatados são os principais indicativos disto. 
Nunca observei, nas diversas redações de jornal ou de televisão que conheci, seja por ter amigos nesses ambientes, seja em função de minha pesquisa de campo, essa fauna de engravatados. Desconheço qual possa ser a redação visitada pelo jornalista, e ele também não a identifica. Mas o que importa, evidentemente, é que a descrição traduz a intensidade do impacto que as divisões desse ambiente provocaram nele. As redações atuais têm os seus espaços cada vez mais demarcados, e sua rotina de trabalho prima pelo caráter nitidamente mais técnico. A separação indicada pelo espaço nessas novas redações apresenta duas outras ordens de divisão: um muro cada vez maior entre a sala de redação e o mundo que esses profissionais supõem noticiar e, outro, entre os próprios profissionais ali dentro. A matéria que irá compor a edição do jornal ou do telejornal tem seu formato, sua linguagem e sua importância definidos em função desses muros que se erguem para a sua produção.

O caráter técnico do trabalho é resultado, em parte, dessas divisões do serviço no interior das salas de redação e, em parte, do esforço de controle e definição de uma escrita própria para o jornalismo, controle este que torna cada vez mais distante reportagens como as feitas por Joel Silveira, o mesmo que narra mais acima sua visita àquela moderna redação, ao longo de sua trajetória. Reportagens para serem lidas e relidas, mas ao mesmo tempo reportagens que, cada vez mais, não podem ser imitadas. Ao menos não por aqueles que ocupam as posições mais desvalorizadas da profissão, uma vez que o uso das formas de linguagem próprias às posições de autoridade e autonomia deve ficar restrito a essas mesmas posições.

A definição de um modelo para a escrita jornalística, por um lado, permitiu a ela assumir uma forma distinta diante dos demais gêneros, em particular o literário, mas, por outro, fez com que a atividade de pesquisa e recolha de informações se ajustasse ao modelo dessa mesma escrita. Além do mais, ela precisa passar por uma posterior revisão para que fique plenamente adequada ao "estilo de redação" do jornal. A coletânea citada anteriormente sobre os personagens que fizeram a imprensa no Brasil descreve da seguinte forma a criação do primeiro "manual de estilo" do país:

O trabalho começou no Carnaval de 1950. Em sua casa, durante os quatro dias de folia carnavalesca, Pompeu de Souza, então chefe de redação do Diário Carioca, redigiu o primeiro manual da redação, o style book. Caía por terra o texto caricaturado, com nariz-de-cera, partidário e panfletário, para nascer o texto informativo e objetivo, ensinado até hoje nas salas de aulas das universidades brasileiras.

O objetivo do jornalista era o de criar uma técnica redacional para a imprensa brasileira, tendo como base a existente nos Estados Unidos. O manual estabele- 
ceu as linhas mestras de uma redação concisa, direta e sem a polêmica da opinião dos jornalistas, ao mesmo tempo em que atraía a atenção do leitor, que passou a encontrar no lead as principais respostas para as perguntas mais corriqueiras que alguém pode fazer quando quer ser informado sobre um acontecimento, O quê? Quem? Onde? Quando? Como? Por quê? (Mendez 2008:232).

A reportagem, até então um trunfo dos jornais nos debates mais importantes realizados, passa a ser realizada como uma atividade dentre outras no interior de uma rotina burocrática:

\begin{abstract}
Alguém poderia atribuir a ausência de teor literário nos jornais de hoje ao processo de modernização da linguagem jornalística promovido no Brasil desde os anos 60. O jornalismo nacional até então era retórico, verborrágico, personalista, apesar de trabalhos de síntese e clareza como os de Rubem Braga e Joel Silveira. Mas, inspirados na escola americana, os reformadores dos jornais nos anos 60 começaram a exigir uma abordagem mais objetiva, menos participante, concentrada em contar histórias sem editorializá-las. Até aí, ótimo. Mas nos anos 80 veio uma nova onda de "modernização", que nos anos 90 consolidaria uma triste realidade: textos relatoriais, burocráticos, com pobreza de palavras e recursos, tanto mais tendenciosos quanto mais se pretendem "neutros" (Piza 2002:134-135).
\end{abstract}

Há, evidentemente, grandes reportagens ainda sendo feitas. Mas há um número muito maior, e crescente, de pequenas reportagens, incapazes de conferir algum prestígio a seus repórteres, e é basicamente sobre elas e seus autores que recaem as cobranças e as restrições relativas à imposição de um "modelo para a escrita", assim como todas as demais restrições ligadas a essas posições entendidas como de menos valor. Talvez essa mudança ainda não tenha se tornado tão visível nos jornais, principalmente nos grandes, apesar de serem eles os responsáveis pela definição e a imposição de um "estilo", mas na televisão ela mostra uma visibilidade inegável:

Pode estar acontecendo tudo ao lado, mas se a repórter não estiver bem penteada, com batom, não vai ao ar. Na Globo — já trabalhei em algumas afiliadas da emissora, mas nunca na sede - qualquer informação tem que ser "segundo fulano". O jornalista nunca pode falar algo que viu, tudo tem que estar na boca dos outros (Correia 1994:55).

O processo de divisão do trabalho jornalístico implicou a introdução de profissionais autorizados para o comentário dos acontecimentos, retirando parte significativa da autoridade que antes o repórter tinha no desempenho 
de sua função. Ele passa a desempenhar o papel de informante ou, melhor ainda, de "contato com a informação", esta encontrada em outra pessoa, cujo depoimento deverá ser devidamente gravado ou anotado e posteriormente transcrito pelo repórter.

Não só o papel do repórter muda, mas também o próprio significado da informação. Ela não é mais algo a que se chega através da reportagem. Passa a ser uma informação sabida de antemão e para a qual cabe uma exposição sumária e didática. Este é o efeito produzido pelo "ajuste" da reportagem a seu modelo predefinido de escrita, entendido como "estilo jornalístico". ${ }^{19}$ A reportagem só se torna uma interpretação pessoal quando autorizada pelo cargo ou pelo prestígio de seu repórter.

A gradativa perda de autoridade do repórter, provocada pela crescente divisão do trabalho jornalístico, aliada à reorganização do mercado de trabalho promovida pela exigência do diploma, implicou, portanto, uma redefinição tanto das funções e das atividades consideradas de maior autoridade e autonomia quanto daquelas de menor valor e prestígio no interior do jornalismo. O jornalismo, antes "trabalho intelectual", agora passa a ser definido, cada vez mais, pelo que tem de "técnico". As posições propriamente "intelectuais" são aquelas que podem ser definidas em função da autoridade e da autonomia obtidas no mercado de títulos e cargos universitários, distante em tudo das pressões e da linguagem (técnica) que marcam as posições mais burocráticas e de menor prestígio do jornalismo.

\section{Manuais de estilo, memória e história}

A definição de um "estilo próprio" de escrita e a adoção de outra série de técnicas para a rotina de trabalho e a produção de jornais, nos anos 1950, representaram uma ruptura entre o jornalismo e a literatura, entre a profissão de jornalista e a profissão de escritor. Conforme aponta Ana Paula Goulart Ribeiro:

A imprensa foi abandonando a tradição de polêmica, de crítica e de doutrina, substituindo-a por um jornalismo que privilegiava a informação (transmitida "objetiva" e "imparcialmente" na forma de notícia) e que a separava (editorial e graficamente) do comentário pessoal e da opinião.

[...] o jornalismo brasileiro, ao ser capaz de assumir cânones discursivos e profissionais próprios, conseguiu assegurar uma certa distância em relação à literatura. Isso não significa que os dois campos (o literário e o jornalístico) se tenham autonomizado totalmente. Muitos escritores ainda eram jornalistas e 
muitos jornalistas se aventuravam na vida literária. As duas atividades eram muito próximas e o contato entre elas, inevitável. Na realidade, literatura e jornalismo pertenciam a um mesmo sistema de bens simbólicos, que só se separaram (e adquiriram uma autonomia relativa) na medida em que foram capazes de constituir mercados distintos, associados a lógicas produtivas diversas (Ribeiro 2003:148, 158).

Essa ruptura permitiu, portanto, a consolidação do jornalismo como um campo autônomo perante a literatura. Mas há também outros aspectos implicados e cujos desdobramentos podem ser observados na tentativa de construção seja de uma identidade, seja de uma memória e de uma história para a profissão.

O primeiro aspecto está ligado à transformação dos dois gêneros, literário e jornalístico, em "marcadores temporais". ${ }^{20}$ Não se trata de um conflito "datado", ele permanece atual porque permite o agenciamento das práticas cotidianas. O "nariz de cera", texto mais próximo da literatura que do jornalismo, é uma forma de escrita que deve ser "deixada para trás". Rodrigo Lobo (2010) chama a atenção para este aspecto nos cursos em que fez sua pesquisa. Por um lado, os professores cobravam certa erudição, por outro, exigiam que essa mesma erudição não estivesse presente na escrita. Cobravam, assim, a necessidade de uma formação cultural, como conhecimento do passado, e a necessidade imperiosa de adaptação ao presente da profissão. Isto faz com que as formas de linguagem sejam permanentemente tomadas como marcadores geracionais, separando os "antigos" dos "novos", ou como marcadores sociais, separando as posições mais autônomas, nas quais estão os mais experientes, daquelas de menor ou sem nenhuma autonomia, em que se concentram os jovens.

O segundo aspecto é relativo à ampliação do número de Escolas de Jornalismo e de Programas de Pós-Graduação em Comunicação e, portanto, a uma redefinição do mercado de trabalho "intelectual" ligado à profissão. Criou-se, com isso, não apenas uma possibilidade de inserção profissional, mas também um espaço de debate e de pesquisa que tem autonomia diante do próprio jornalismo, onde concorrem os mais titulados, ainda que todos — ou quase todos tenham sido anteriormente jornalistas. Estes profissionais podem, desta maneira, olhar para o jornalismo de forma distanciada e, assim, olhar para seu próprio passado recente, discutindo questões relativas ao presente no jornalismo, ou para o passado da profissão de forma cada vez mais sistemática.

O terceiro aspecto está ligado ao caráter técnico da profissão que passou a ser definidor das suas rotinas de trabalho. Funções burocráticas as mais diversas e não dependentes de uma formação "intelectual" puderam ser incor- 
poradas, ainda que não sem conflitos, ao jornalismo. ${ }^{21}$ É o caso, por exemplo, da questão envolvendo as assessorias de imprensa ${ }^{22}$ ou, mais especificamente, o trabalho nas redações e os trabalhos "extrarredação". Esse mesmo caráter técnico implicou também mudanças significativas tanto na forma quanto no status das reportagens no interior das redações e, com isso, no seu próprio papel como definidor da profissão e da identidade jornalística.

O quarto e último aspecto é um claro desdobramento dos anteriores. As mudanças observadas no jornalismo implicaram uma reorganização profunda da profissão, a tal ponto que se impôs a necessidade de redefinição não simplesmente de uma identidade para ela, mas também de seus marcos e nomes fundadores, de compreensão e escrita de uma história que, se comparada com o presente da profissão, parece distante e sem relação direta com ele. Nesse sentido, o esforço de reconstrução de uma história, assim como do "valor histórico" do jornalismo, vem atrelado a uma redefinição do presente e, portanto, a uma redefinição de sua identidade e de seu valor social.

Recebido em 8 de fevereiro de 2011

Aprovado em $1^{\circ}$ de agosto de 2011

Alexandre Bergamo é professor do Departamento de Sociologia e Ciência Política e do Programa de Pós-Graduação em Sociologia Política da Universidade Federal de Santa Catarina - UFSC, e também do Programa de Pós-Graduação em Ciências Sociais da UNESP - Campus de Marília. E-mail: <a_bergamo@ hotmail.com>.

\section{Notas}

* Esta pesquisa foi desenvolvida com recursos de Bolsa Pós-Doutorado Júnior concedida pelo CNPq e está vinculada ao Projeto Temático de Pesquisa "Formação do Campo Intelectual e da Indústria Cultural no Brasil Contemporâneo", coordenado pelo prof. Sergio Miceli (USP), Processo 2008/55377-3 da FAPESP. Sou muito grato a todos os membros do Projeto pelas críticas e sugestões recebidas para o desenvolvimento deste trabalho e, especialmente, à leitura minuciosa e à possibilidade de discussão do texto original com Jacques Mick. 
${ }^{1}$ Um balanço da questão, e mais especificamente da produção do Programa de Pós-Graduação em Comunicação da UFF / Universidade Federal Fluminense, pode ser encontrado em Albuquerque (2004).

${ }^{2}$ Estimativa elaborada por Mick (2010).

${ }^{3}$ Ver, por exemplo, Ferreira Jr (2003) e Cosson (2007).

${ }^{4} \mathrm{O}$ presente tópico consiste em uma versão reformulada do texto apresentado no GT "Antropologia e Comunicação" na II Reunião Equatorial de Antropologia. Ver Bergamo (2009).

${ }^{5}$ Isso não é regra geral. Em outros veículos, o que se observa é o simples descarte da matéria.

${ }^{6}$ Sobre a diferença entre as matérias "quentes" e "frias" também para o jornalismo impresso e o rádio, ver Travancas (1993).

${ }^{7}$ Sobre a homogeneização da informação na televisão, ver Bourdieu (1997).

${ }^{8}$ Ver, por exemplo, o trabalho de Arbex Jr (2001).

${ }^{9}$ Podem ser encontradas narrativas extraordinárias no mercado dos impressos em períodos bem anteriores ao nosso. Vejamos, por exemplo, o levantamento feito por Roger Chartier: "Entre as 517 edições de pasquins descobertos entre 1530 e 1630, seis motivos predominam, com mais de trinta edições cada um: os crimes e as execuções capitais (89 edições), as aparições celestes (86 edições, às quais podemos acrescentar oito edições de visões do grande Turco), os feitiços e possessões diabólicas (62 edições), os milagres (45 edições), as inundações (37 edições), os tremores de terra (32 edições). Vêm em seguida os sacrilégios, as criaturas monstruosas, os roubos, os raios. Leitura de alfabetizados, já que o texto aqui predomina sem por isso fazer desaparecer a imagem, o pasquim alimenta as imaginações citadinas com narrativas em que o excesso, seja ele o do desregramento moral seja o da desordem dos elementos, e o sobrenatural, miraculoso ou diabólico, rompem com o ordinário do cotidiano" (Chartier 2004:116). Embora as semelhanças sugiram certa continuidade, que também Darnton (1995) fez questão de frisar, ainda que por motivos diferentes, quero chamar a atenção não só para as diferenças de contexto, em que o nosso se caracteriza por uma "escrita racional, regular e profissional", mas também para os menos notados diferentes usos da linguagem, na atualidade, em função do caráter cotidiano ou extracotidiano desses eventos. Fora desse contexto, de obrigação rotineira e profissional de escrita e narração dos fatos ordinários ou extraordinários, talvez não encontrássemos esses diferentes usos da linguagem.

${ }^{10}$ Sou, com isso, relutante quanto a certas definições do jornalismo que supõem que ele possa ser formado por um habitus comum para a profissão (Barros Filho \& Martino 2003) ou por um mecanismo disciplinar que age sobre todos igualmente (Gomes 2003; Biroli 2007). Creio que essas definições, que se baseiam na suposição de uma "unidade", 
tendem, nos termos de Thompson (1998:17), a "distrair nossa atenção das contradições sociais e culturais, das fraturas e oposições existentes dentro do conjunto".

${ }_{11}$ Para uma discussão mais ampliada sobre a produção de documentos, ver Pollak (1989) e Le Goff (2003). Um número considerável de pesquisas na área de jornalismo tem se dedicado, mais recentemente, a uma indagação mais sistemática sobre história e memória na profissão. Ver, a exemplo disso, a coletânea organizada por Ribeiro \& Ferreira (2007) e a tese de doutoramento de Matheus (2010).

${ }^{12}$ A inserção dos assessores de imprensa dentro da categoria de jornalista não se deu, portanto, sem conflitos. Sobre isso, ver Roxo da Silva (2007). Interessante notar que essa inserção foi possível graças a certo apagamento dos traços burocráticos da atividade e da ênfase na necessidade de uma formação específica para a produção não de notícias, mas de "informes".

${ }^{13}$ Esse controle ocorre para que a rotina de trabalho e de escrita possa ser ajustada aos cânones do jornalismo definidos a partir dos chamados "manuais de redação e estilo". Esta questão será mais bem abordada mais adiante no texto.

${ }^{14}$ Para uma etnografia das rotinas ligadas aos cursos de formação de jornalistas oferecidos pelos jornais Folha de São Paulo e O Estado de São Paulo, assim como do treino diário que esses mesmos cursos realizam visando a um perfeito ajuste desses novos profissionais a uma "escrita jornalística", ver Lobo (2010).

${ }^{15}$ Um amplo levantamento histórico dos conflitos envolvendo a obrigatoriedade do diploma para o exercício da profissão de jornalista pode ser encontrado em Roxo da Silva (2007).

${ }^{16}$ O Brasil conta, atualmente, com 133 cursos de Jornalismo (15 em instituições públicas, 118 em instituições privadas) e 371 cursos de Comunicação Social (40 em instituições públicas, 331 em instituições privadas), boa parte deles com Habilitação para Jornalismo. Dados obtidos junto ao portal do E-Mec em janeiro de 2011.

${ }^{17}$ Ver também a coletânea elaborada recentemente pelo Intervozes (2006).

${ }^{18}$ A ideia de que o ambiente da rua é o "seu ambiente" também está presente numa de suas mais importantes reportagens, A milésima segunda noite da Avenida Paulista. Ver Silveira (2003).

${ }^{19}$ Segundo Mouillaud (2002:30), "o dispositivo prepara para o sentido".

${ }^{20}$ Evidentemente, o conflito não se reduz a isso. Vários depoimentos chamam a atenção para a desqualificação e a falta de erudição de uma série de jornalistas, principalmente aqueles ligados ao jornalismo policial. Sobre isso, ver Roxo da Silva (2007).

${ }^{21}$ Embora, como chamam a atenção Albuquerque \& Roxo da Silva (2007), o modelo norte-americano de jornalismo materializado nos manuais de redação e estilo 
só tenha conseguido se impor graças à formação intelectual e militante dos jornalistas ligados ao Partido Comunista nos anos 1950, capaz de garantir a disciplina necessária ao novo modelo de trabalho.

${ }^{22}$ Um balanço da questão pode ser encontrado em Roxo da Silva (2007).

\section{Referências bibliográficas}

AJZENBERG,Bernardo. 2002. "Dois senhores". In: Gustavo de Castro \& Alex Galeno (orgs.), Jornalismo e literatura: a sedução da palavra. São Paulo: Escrituras. pp. 53-55.

AlbuQUERQUe, Afonso de. 2004. "A identidade jornalística no Brasil: algumas questões teóricas e metodológicas". E-Compós, 1:1-14. . \& ROXO DA SILVA, Marco Antonio. 2007. "Preparados, leais e disciplinados: os jornalistas comunistas e a adaptação do modelo de jornalismo americano no Brasil". E-Compós, 9:1-30.

ALQUÉRES, Hubert. 2005. "Apresentação". In: José Marques de Melo (org.), Imprensa brasileira: personagens que fizeram história. 2 vols. São Paulo: Universidade Metodista de São Paulo/ Imprensa Oficial do Estado de São Paulo. pp. 11-12.

ARBEX JR., José. 2001. Showrnalismo: a notícia como espetáculo. São Paulo: Casa Amarela.

BARCELOS, Caco. 1994. "Repórter: profissão perigo". In: Sheila Kaplan \& Sidney Rezende (orgs.), Jornalismo eletrônico ao vivo. Petrópolis: Vozes. pp. 17-31.

BARROS FILHO, Clóvis de \& MARTINO, Luís Mauro Sá. 2003. O habitus na comunicação. São Paulo: Paulus.
BERGAMO, Alexandre. 2009. "Todo dia é a mesma coisa": rotina do telejornalismo e produção de notícias. GT Antropologia e Comunicação. Anais da II Reunião Equatorial de Antropologia e XI Reunião de Antropólogos do Norte-Nordeste. pp. 1-12.

BIROLI, Flávia. 2007. “Técnicas de poder, disciplinas do olhar: aspectos da construção do 'jornalismo moderno' no Brasil". História, 26(2):118-143.

BOURDIEU, Pierre. 1997. Sobre a televisão. Rio de Janeiro: Zahar.

CHARTIER, Roger. 2004. Leituras e leitores na França do Antigo Regime. São Paulo: Editora da Unesp.

CORREIA, Leonor. 1994. "À frente do auditório". In: Sheila Kaplan \& Sidney Rezende (orgs.), Jornalismo eletrônico ao vivo. Petrópolis: Vozes. pp. 53-60.

COSSON, Rildo. 2007. Fronteiras contaminadas. Brasília: Editora UnB.

DANTAS, Audálio (org.). 1998. Repórteres. São Paulo: Senac.

DARNTON, Robert. 1995. O beijo de Lamourette: mídia, cultura e revolução. São Paulo: Cia. das Letras.

FAERMAN, Marcos. 1998. "A longa aventura da reportagem". In: Audálio Dantas (org.), Repórteres. São Paulo: Senac. pp. 145-163. 
FERREIRA JÚNIOR, Carlos Antonio Rogé. 2003. Literatura e jornalismo, práticas políticas: discursos e contradiscursos, o Novo Jornalismo, o romance-reportagem e o livro-reportagem. São Paulo: Edusp.

GOMES, Mayra Rodrigues. 2003. Poder no jornalismo: discorrer, disciplinar, controlar. São Paulo: Hacker Editores/ Edusp.

INTERVOZES. 2006. Vozes da democracia: histórias da comunicação na redemocratização do Brasil. São Paulo: Imprensa Oficial do Estado de São Paulo.

KOTSCHO, Ricardo. 1998. "O pipoqueiro e os filhos da pauta". In: Audálio Dantas (org.), Repórteres. São Paulo: Senac. pp. 183-197.

KUCINSKI, Bernardo. 2003. Jornalistas e revolucionários: nos tempos da imprensa alternativa. 2. ed. revista e ampliada. São Paulo: Edusp.

LE GOFF, Jacques. 2003. História e memória. 5. ed. Campinas: Editora da Unicamp.

LOBO, Rodrigo Gomes. 2010. Processos de socialização em jornalismo: adestrando "focas" e treinando trainees. Dissertação de mestrado, Programa de Pós-Graduação em Antropologia Social, FFLCH - USP.

MARQUES DE MELO, José (org.). 2005a; 2008. Imprensa brasileira: personagens que fizeram história. São Paulo: Universidade Metodista de São Paulo/ Imprensa Oficial do Estado de São Paulo. , 2005b. "Prefácio". In: José Marques de Melo (org.), Imprensa brasileira: personagens que fizeram história. São Paulo: Universidade Metodista de São Paulo/ Imprensa Oficial do Estado de São Paulo. pp. 7-9.

MATHEUS, Letícia Cantarela. 2010. Comunicação, tempo, história: tecendo o cotidiano em fios jornalísticos. Tese de doutorado, Programa de Pós-Graduação em Comunicação, UFF.

. 2010a. "A chegada do inverno ou o que tenho a ver com Kuala Lumpur". E-Compós, 13(3):1-15.

MEMÓRIA GLOBO. 2004. Jornal Nacional: a notícia faz história. Rio de Janeiro: Zahar.

MENDEZ, Rosemary Barz. 2008. "Pompeu de Souza, o jornalista que transformou o jornalismo brasileiro". In: José Marques de Melo (org.), Imprensa brasileira: personagens que fizeram história. Vol. 3. São Paulo: Universidade Metodista de São Paulo/ Imprensa Oficial do Estado de São Paulo. pp. 225-240.

MICK, Jacques. 2010. "Perfil profissional do jornalismo brasileiro". Projeto Integrado de Pesquisa, versão preliminar, $\mathrm{CFH}$, UFSC. Mimeo.

MOUILLAUD, Maurice. 2002. "Da forma ao sentido". In: Sérgio Dayrell Porto (org.), O jornal: da forma ao sentido. 2. ed. Brasília: Editora UnB. pp. 29-35.

PIZA, Daniel. 2002. "Jornalismo e literatura: dois gêneros separados pela mesma língua". In: Gustavo de Castro \& Alex Galeno (orgs.), Jornalismo e literatura: a sedução da palavra. São Paulo: Escrituras. pp. 133-137.

POLLAK, Michael. 1989. "Memória, esquecimento, silêncio". Revista Estudos Históricos, 2(3):3-15.

RIBEIRO, Ana Paula Goulart. 2003. "Jornalismo, literatura e política: a modernização da imprensa carioca nos anos 1950". Revista Estudos Históricos, 1(31):147-160.

RIBEIRO, Ana Paula \& BRASILIENSE, Danielle Ramos. 2006. "'A matança dos inocentes': questões de memória e narrativa jornalística". UNIrevista, 1(3):1-12.

RIBEIRO, Ana Paula \& FERREIRA, Lúcia Maria Alves. 2007. Mídia e memória: a produção de sentidos nos meios de comunicação. Rio de Janeiro: Mauad X. 
RICOEUR, Paul. 2007. A memória, a história, o esquecimento. Campinas: Editora da Unicamp.

ROXO DA SILVA, Marco Antonio. 2007. Jornalistas, pra quê? Militância sindical e o drama da identidade profissional. Tese de doutorado, Programa de Pós-Graduação em Comunicação, UFF.

SILVA, Juremir Machado da. 2002. "O que escrever quer calar? Literatura e jornalismo". In: Gustavo de Castro \& Alex Galeno (orgs.), Jornalismo e literatura: a sedução da palavra. São Paulo: Escrituras. pp. 47-52.

SILVEIRA, Joel. 1998. "Conversa de dromedário". In: Audálio Dantas (org.), Repórteres. São Paulo: Senac. pp. 87-103. 2003. A milésima segunda noite da Avenida Paulista. São Paulo: Companhia das Letras.

SIlveirA, Mauro César. 1992. "Quando o patrulhamento é necessário". Intercom - Revista Brasileira de Comunicação, XV(2):207-210.

SODRÉ, Muniz. 2008. "Muito além do diploma". In: Fenaj (org.), Formação superior em jornalismo: uma exigência que interessa à sociedade. Florianópolis: Fenaj. pp. 51-55.

THOMPSON, E. P. 1998. Costumes em comum: estudos sobre a cultura popular tradicional. São Paulo: Companhia das Letras.

TRAVANCAS, Isabel Siqueira. 1993. O mundo dos jornalistas. São Paulo: Summus. 
Resumo

O presente artigo procura demonstrar de que modo mudanças recentes no exercício da profissão de jornalista estão sendo capazes de redefinir a forma como esses profissionais olham para si mesmos no presente e, consequentemente, para seu passado, para sua própria "história". Para tanto, me apoio em minha própria e em outras etnografias do jornalismo - em particular do espaço da redação - na especificidade da "notícia" e, principalmente, da "reportagem" enquanto "documento" histórico, discussão necessária para a compreensão da vinculação que se estabelece entre a "memória jornalística" e a "memória nacional"; e nos efeitos que a imposição de um "estilo jornalístico", a exigência do diploma e a reorganização do mercado de trabalho tiveram - e têm sobre a organização e a escrita, cada vez mais sistematizada, das trajetórias consideradas exemplares para a área.

Palavras-chave Jornalismo, Memória, Manuais de Estilo, Cultura, Indústria Cultural.
Abstract

The present article explores how recent changes in journalism have redefined the way in which the area's professionals see themselves in the present and so how they see their past, their own 'history.' I draw from my own and other ethnographies of journalism, particularly those focused on the editorial office, in order to examine the specificity of 'news' and especially 'reporting' as a historical 'document,' a discussion essential to understanding the link between 'journalistic memory' and 'national memory.' The text also discusses the effects that the imposition of a 'journalistic style,' the need for formal qualifications and the reorganization of the work market have had - and continue to have - on the increasingly systemized organization and description of careers now considered emblematic in the profession.

Key words: Journalism, Memory, Style Manuals, Culture, Culture Industry. 